\title{
Islamic Tolerance in World 4.0: Membentuk Kepribadian Toleran dan Hubungannya dengan Self-Control dalam Bersosial Media
}

\author{
Sabrina Adani Widiatmoko, Keny Pek, Fahmi Eko Nur Iman, Annisa T R, Fitri Wulandari, \\ Oksita Nurma Gupita, Ahmad Rusdi* \\ Pusat Studi Psikologi Islam, Fakultas Psikologi dan Sosial Budaya, Universitas Islam Indonesia \\ *Corresponding Email: ahmad_rusdi@uii.ac.id
}

\begin{abstract}
ABSTRAK
Tujuan dalam pengabdian ini adalah untuk mengetahui pengaruh perubahan sikap toleransi dengan dilaksanakannya kegiatan pengabdian masyarakat dalam upaya untuk memberi edukasi terkait pentingnya meningkatkan sikap tolernasi di era modern ini untuk mengurangi fenomena intoleransi. Pengabdian ini dilakukan melalui media zoom dalam bentuk web seminar atau webinar. Metode pengabdian yang dilakukan adalah metode pengabdian eksperimental dengan dengan melibatkan 74 peserta dengan desain one group pretest postest. Data dihimpun dalam bentuk kuesioner. Teknik analisis data dengan cara uji Wilcoxon dengan program SPSS versi 24.0. Hasil pengabdian menunjukkan bahwa webinar Islamic Tolerance in World 4.0 memiliki pengaruh yang signifikan terhadap sikap toleransi. Hal ini ditunjukkan dengan kenaikan rata-rata pretest ke postest sebesar 1,17 dan dengan hasil signifikansi 0,026 dengan nilai $\mathrm{p}<0,05$.
\end{abstract}

Kata Kunci: Islamic Tolerance, Keperibadian

\section{ABSTRACT}

The purpose of this study was to determine the effect of changes in tolerance by carrying out community service activities in an effort to provide education regarding the importance of increasing tolerance in this modern era to reduce the phenomenon of intolerance. This research was conducted through zoom media in the form of web seminars or webinars. The research method used is an experimental research method involving 74 participants with a one group pretest postest design. The data were collected in the form of a questionnaire. The data analysis technique used the Wilcoxon test with the SPSS version 24.0 program. The results showed that the Islamic Tolerance in World 4.0 webinar has a significant effect on tolerance. This is indicated by the increase in the average pretest to posttest of 1.17 and with a significance result of 0.026 with a p value $<0.05$.

Keywords: Islamic Tolerance, Personality.

\section{PENDAHULUAN}

Secara umum konflik antar pemeluk agama disebabkan oleh beberapa faktor, seperti timbulnya aksi pelecehan terhadap suatu agama atau pemimpin spiritual agama tertentu, terdapat perbedaan ajaran, larangan dan perintah dari setiap agama, hingga membuat para pengikut dari agama - agama saling berdebat untuk membuktikan mana teori yang paling benar. Dalam konteks toleransi antar umat beragama, Islam memiliki konsep yang jelas. Tidak ada pemaksaan agama, hal ini merujuk pada Firman Allah SWT QS. Al-Kafirun ayat 6 yang artinya 'Untukmu Agamamu, dan Untukkulah Agamaku'. Islam menghendaki pemeluknya untuk menebar toleransi (tasamuh) serta menjauhi sikap buruk sangka terhadap agama lain (Khotimah, 2013). Karena pada haikatnya toleransi dapat diartikan sebagai usaha kebaikan, khususnya kemajemukan agama yang memiliki tujuan luhur yaitu tercapainya kerukunan, baik sesame pemeluk agama maupun antar agama. Jika konflik antar agama 
tersebut dibiarkan, maka akan sangat berbahaya yang ditandai oleh beberapa fenomena intoleransi yang terjadi di Indonesia, yaitu penyerangan terhadap rumah ibadah, terjadi fenomena vandalisme, hingga kerusakan lainnya yang telah memakan korban jiwa akibat aksi konflik antar agama. Hal ini tentunya berdampak pada tatanan kehidupan dalam masyarakat. Secara etimologis, toleransi berasal dari bahasa Inggris, toleration. Toleransi berarti sikap membiarkan orang lain untuk dapat melakukan sesuatu sesuai dengan kepentingannya (Muharam, 2020). Sedangkan toleransi beragama merupakan masing-masing umat beragama, yakni menjaga suasana tetap kondusif bagi umat atau pemeluk agama lain sehingga untuk pelaksanaan ibadah dengan beragama tidak dapat halangan oleh siapapun Membangun toleransi umat beragama di Indonesia tentu saja memiliki berbagai tantangan untuk dapat mewujudkannya. Tak hanya itu semakin kencang sikap intoleransi agama yang berkaitan erat dengan politik membuat masyarakat Indonesia hampir terpecah belah. Perlu adanya kesadaran dalam masyarakat bahwa sikap toleransi perlu dipupuk dan dijaga untuk membangun rasa persatuan dan kesatuan bangsa agar tidak terjadi bentrokan massa. Adanya saling curiga antara satu kelompok yang satu dengan yang lainnya. Untuk menghindari suatu bentrokkan antar kelompok agama, sekte agama ataupun pandangan lain yang berkaitan dengan agama tentu saja perlu adanya kesadaran antar umat beragama yang dapat menekan atau meminimalisir adanya bentrokan. Agar menghindari suatu bentrokan atau sikap saling curiga antara satu dengan yang lainnya perlu adanya interaksi sosial yang lebih intens. Kesadaran sikap toleransi tidak begitu saja dapat dipahami oleh sebagaian masyarakat Indonesia yang sangat multikultural. Bentuk interaksi sosial yang diakomodasi tentunya akan membentuk suatu toleransi (Muharam, 2020).

Toleransi beragama tidak berarti bahwa seseorang yang telah mempunyai keyakinan kemudian berpindah atau merubah keyakinannya untuk mengikuti dan berbaur dengan keyakinan atau peribadatan agama - agama lainnya (sinkretisme), tidak pula dimaksudkan untuk mengakui kebenaran semua agama maupun kepercayaan, melainkan seseorang tersebut tetap berada pada suatu keyakinan yang diyakini kebenarannya, serta memandang benar keyakinan orang lain, sehingga dalam dirinya terdapat kebenaran yang diyakininya sendiri menurut suara hatinya yang tidak diperoleh atas dasar paksaan orang lain ataupun diperoleh dari pemberian orang lain (Casram, 2016).

\section{Rekam Jejak Peristiwa Intoleransi di Indonesia}

Sejak tahun 2012 hingga kini Indonesia dihadapkan oleh berbagai isu problematika toleransi keagamaan, dimana hal ini ditunjukkan oleh berbagai kejadian perusakan tempat ibadah yang tersebar di beberapa kota. Data yang bersumber dari Komnas HAM menunjukkan bahwa pada tahun 2015 terjadi 87 pengaduan masyarakat dengan 37 tindakan pelanggaran KBB atau pelanggaran Kebebasan Beragama dan Berkeyakinan, yang meliputi pelarangan adanya proses ibadah, perusakan tempat ibadah, dan menghalangi berdirinya rumah ibadah (gereja dan masjid). Lebih lanjut The Wahid Institute menunjukkan pada tahun 2014 terjadi 158 peristiwa dengan 187 kasus tindakan penyerangan rumah ibadah yang paling banyak dengan total 17 kasus. Sebanyak 80 peristiwa atau setara dengan presentase $50 \%$ tindakan KBB dilakukan oleh pelaku negara, sementara $48 \%$ atau sekitar 78 peristiwa tindakan dilakukan oleh pelaku non-negara. Berdasarkan laporan yang ditulis oleh Setara Institute di tahun 2018 menunjukkan data pada tahun 2013 \& 2015 telah terjadi peristiwa KBB terhadap rumah ibadah yaitu Pura, Vihara, Masjid, dengan total 31 peristiwa. Sementara itu di tahun 2014 telah terjadi 134 peristiwa KBB dengan jumlah 177 tindakan, dan pada tahun 2015 terjadi 196 peristiwa dengan 236 tindakan. Sehingga tercatat selama 9 tahun sejak 2007 hingga 2015 terdapat total 331 kasus tempat ibadah mengalami pembakaran, perusakan, hingga tidak mendapat perizinan untuk melakukan proses pembangunan. Selain itu di tahun 2016 total keseluruhan peristiwa KBB yang dilakukan oleh pelaku non-negara sebanyak 138 kasus dan pelaku negara sebanyak 98 kasus. Tindakan pelanggaran KBB tersebut meliputi penyegelan tempat ibadah, pembongkaran tempat ibadah yang sedang dalam proses pembangunan, perusakan tempat ibadah, hingga pembubaran acara keagamaan. Terhitung sejak 2012 hingga 2016 terdapat lima provinsi tertinggi peristiwa KBB, pertama provinsi Jawa Barat, kedua DKI Jakarta, ketiga Jawa Timur, keempat Aceh, dna kelima D.I.Yogyakarta.

Dilansir dari artikel Setara Institute yang ditulis pada tahun 2018, peristiwa perusakan tempat ibadah berlanjut di tahun 2017 hingga 2018, dimana sebanyak 21 peristiwa yang meliputi tindakan 
intoleransi berupa provokasi dan diskriminasi, penyesatan berupa ujaran kebencian, dan tindakan penggerebekan rumah ibadah. Atas peristiwa tersebut, tercatat sejumlah korban sebanyak 55 dan berasal dari 7 peristiwa yang melibatkan umat Islam, mahasiswi sebanyak 5 peristiwa, ulama sebanyak 5 peristiwa, dan umat Katolik sebanyak 5 peristiwa. Di tahun 2018 pada Juni tanggal 30 tercatat sebanyak 109 peristiwa dengan 136 tindakan yang tersebar di 20 provinsi Indonesia, dimana 5 provinsi tertinggi kasus pelanggaran KBB yakni provinsi DKI Jakarta sebanyak 23 peristiwa, provinsi Jawa Barat sebanyak 19 peristiwa, provinsi Jawa Timur sebanyak 15 peristiwa, provinsi D.I.Yogyakarta sebanyak 9 peristiwa dan terakhir provinsi Nusa Tenggara Barat sebanyak 7 peristiwa. Dari jumlah peristiwa pelanggaran KBB tersebut, pelaku dilakukan oleh oknum negara sebanyak 40 pelanggaran yang dilakukan oleh pihak kepolisian, pemerintah daerah, dan institusi pendidikan, dan oknum non-negara yang tercatat sebanyak 96 pelanggaran yang pelakunya merupakan individu/warga dan individu yang tergabung dalam organisasi masyarakat.

Sementara itu kasus intoleransi yang terjadi di Indonesia berupa peristiwa perusakan tempat ibadah kembali terjadi di tahun 2019 hingga tahun 2020. Dilansir dari artikel berita BBC di tahun 2018, telah terjadi peledakan bom di 3 tempat ibadah di Surabaya, Jawa timur yakni gereja katolik santa maria, gereja pantekosta, dan gereja GKI pada Minggu, 13 Mei 2018 dan tercatat bahwa korban yang tumbang sebanyak 10 orang serta 40 lainnya mengalami luka - luka. Lebih lanjut insiden perusakan tempat ibadah, yaitu masjid Baiturrahman Tuban, Jawa Timur pada Minggu, 13 februari 2018 telah dirusak oleh pelaku berusia 40 tahun yang diduga mengalami gangguan jiwa. Pada bulan yang sama, tepatnya 11 Februari 2018 penyerangan gereja st. Lidwina di Sleman, Yogyakarta saat para jemaat sedang melakukan misa, tak hanya itu telah diungkap bahwa pelaku kauss ini melukai seorang pastor dengan menggunakan pedang. Di tahun 2020 kejadian perusakan rumah ibadah yang merupakan salah satu bentuk intoleransi umat beragama kembali terjadi tepatnya pada Selasa, 29 September 2020 dimana musala Baiturrahman di Tangerang, Banten telah dirusak oleh seorang pelaku yang kembali diduga mengalami permasalahan psikologis. Pelaku berusia 18 tahun tersebut melakukan pencoretan terhadap tembok musala, merobek kitab suci Al-Qur'an, dan menggunting karpet musala (Putra, 2020).

Berbagai fakta peristiwa mengenai perusakan tempat ibadah yang merupakan bentuk dari intoleransi umat beragama masih sering ditemukan di beberapa kota di Indonesia. Hal ini menjadi situasi yang urgensi dimana diketahui dari berbagai fakta bahwa Indonesia masih darurat akan sikap toleransi pada diri masyarakat, sehingga hal ini memicu banyak terjadinya provokator oleh oknum yang tidak diketahui, kemudian beralih menyebarkan isu - isu hoax di media sosial dan berkahir pada eksekusi peristiwa penyerangan tempat ibadah. Atas dasar tersebut maka sebagai remaja muslim sekaligus sebagai mahasiswa, akan melakukan kegiatan pengabdian masyarakat berupa aktivitas web seminar yang mengangkat tema Islamic Tolerance in World 4.0 dan hipotesis yang diusung ialah bahwa dengan adanya kegiatan web seminar ini makan akan terjadi perubahan skor sikap toleransi yang meningkat antara sebelum dan sesudah dilaksanakannya kegiatan pengabdian masyarakat tersebut dalam upaya untuk memberi edukasi terkait pentingnya meningkatkan sikap tolernasi di era modern ini untuk mengurangi fenomena intoleransi di Indonesia.

\section{METODE PELAKSANAAN KEGIATAN PENGABDIAN MASYARAKAT WEB SEMINAR ISLAMIC TOELRANCE IN WORLD 4.0}

Masa pandemi yang sedang terjadi saat ini membuat kegiatan seminar yang biasa diadakan secara tatap muka, sekarang acara seminar hanya dapat diadakan secara online. Hal ini dilakukan agar tidak bertambahnya kasus COVID-19 khususnya di Indonesia. Kegiatan seminar yang kami lakukan menggunakan metode web seminar. Web seminar seminar yang dilakukan langsung melalui web dan didesain interaktif. Konsep "Webinar" diambil dari kalimar "web-based seminar". Untuk mengikuti webinar, peserta dapat menghubungi via telepon atau mendengarkan secara langsung pembicara melalui komputer yang terhubung melalui akses internet. 
Web seminar atau seminar online merupakan metode yang layak untuk mengedukasi lintas situs institusional (Izza et al., 2019). Webinar yang kami laksanakan di tengah pandemi seperti ini yaitu menggunakan aplikasi video conference yaitu Zoom. Menurut Yulianto et al., (2020) Zoom merupakan platform tatap muka yang bersifat conference dimana pendidik dan peserta didik bisa langsung berinteraksi layaknya bertemu langsung. Aplikasi Zoom banyak digunakan dalam proses pembelajaran di masa pandemi, yang memudahkan pendidik memberikan ilmunya kepada peserta didik, selain itu Zoom juga dapat memberikan kemudahan dalam mengedukasi masyarakat secara online. Pelaksanaan acara webinar melalui Zoom cukup membantu dalam melaksanakan kegiatan, aksesnya yang mudah serta dapat memuat banyak partisipan, menjadikan aplikasi Zoom yang cukup membantu dalam melaksanakan seminar secara online. Sehingga acara webinar yang kami lakukan mampu terlaksana dengan baik, ditengah pandemi seperti saat ini masih banyak masyarakat khususnya mahasiswa yang cukup antusias untuk berpartisipasi dalam webinar yang kami adakan.

Selain itu dalam menunjang berlangsungnya webinar, kami juga menggunakan apliaksi WhatsApp. Menurut Yulianto et al., (2020) WhatsApp digambarkan sebagai alat untuk berinteraksi dengan teman maupun pengajar mengenai topik tertentu, obrolan dan berbagi informasi sebagian besar terjadi dalam WhatsApp grup yang dibuat oleh administrator. Dalam menggunakan WhatsApp, kami membuat whatsapp group dengan tujuan dapat memudahkan panitia dalam berinteraksi, memberikan informasi mengenai pre-test dan post-test untuk membantu pengabdian kami dan untuk memantau partisipan sebelum, ketika berlangsungnya acara, serta setelah berlangsungnya acara webinar untuk memberikan informasi mengenai sertifikat yang kami bagikan.

Karena masyarakat masih keliru akan pentingnya toleransi umat beragama, maka menurut kami sebagai peneliti dengan diterapkannya suatu metode dengan tujuan sebagai solusi problematika umat, maka perlu dilakukannya pelaksanaan kegiatan web seminar untuk mengatasi permasalahan intoleransi. Melalui kegiatan edukasi web seminar maka diharapkan masyarakat dapat memahami makna dari toleransi umat beragama dalam sudut pandang Islam. Kegiatan ini memiliki tema 'Pentingnya Toleransi Beragama dalam Perspektif Islam', dimana tema tersebut memiliki makna bahwa pemahaman dan penerapan nilai - nilai toleransi itu penting untuk idmiliki oleh setiap individu sehingga setiap manusia diharapkan mampu mengimplementasikan values tersebut dalam kehidupan sehari - hari bersama masyarakat lainnya. Selnajutnya kegiatan web seminar yang dijalankan oleh peneliti bertajuk Islamic Tolerance in World 4.0: Membentuk Kepribadian Toleran dan Hubungannya dengan Self-Control dalam Bersosial Media. Program ini ditujukan untuk seluruh partisipan yang merupakan masyarakat umum dan berasal dari berbagai jenjnag pendidikan di Indonesia. Berikut merupakan bagan mengenai cara kerja program edukasi pengabdian pada masyarakat.

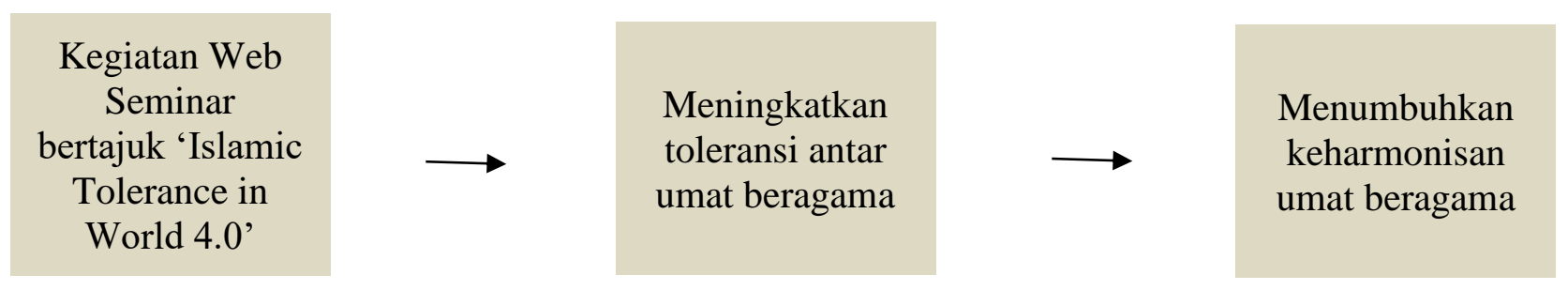

Bagan 1. Cara Kerja Program Edukasi Web Seminar

Target yang telah ditetapkan oleh peneliti sangat relevan dengan tema kegiatan yang merujuk pada pedoman kitab suci Al-Qur'an sebagai pedoman dasar. Selain itu menilik kembali pada peristiwa intoleransi yang telah terjadi sejak 2012 hingga sekarang menjadi alasan kuat peneliti dalam upaya untuk memberi edukasi kepada masyarakaat yang diharapkan dapat memperoleh pengetahuan yang bermanfaat sehingga kejadian serupa tidak akan terulang kembali, hal tersebut sejalan dengan tujuan kegiatan yang telah ditetapkan oleh peneliti yakni untuk meningkatkan sikap toleransi umat muslim kepada umat non-muslim sehingga dapat menurunkan terjaidnya konflik antar umat beragama. Dalam proses pencarian audience atau partisipan, peneliti membuat form pendaftaran digital menggunakan google form yang berisi informasi seputar kegiatan dan identitas peserta yang harus diisi. Target 
peserta yang ditetapkan oleh peneliti untuk dapat bergabung di kegiatan web seminar berjumlah 100 peserta tanpa syarat. Sebelum kegiatan pelaksanaan web seminar para peserta terlebih dulu diberikan form pre-test yang merupakan pengukuran awal untuk mengetahui skor sikap toleransi yang dimiliki oleh peserta. Pengukuran ini didasarkan oleh alat ukur dengan skala Religious Tolerance oyang disusun oleh Broer et al., (2014) yang terdiri dari 52 aitem, namun kami sebagai peneliti memangkas aitem - aitem tersebut menjadi 15 bulir aitem bersifat favourable, dengan penilaian skala likert yang terdiri dari empat alternatif jawaban yaitu Sangat Tidak Setuju (STS), Tidak Setuju (TS), Setuju (S), Sangat Setuju (SS). Setelah pemberian pre-test sebagai pengukuran awal, maka setelah kegiatan web seminar berlangsung peserta kembali diberikan form pengukuran akhir atau post-test untuk mengetahui skor sikap toleransi peserta kegiatan setelah mengikuti kegiatan web seminar dengan menggunakan skala yang sama saat pre-test.

Proses pelaksanaan kegiatan web seminar yang telah dilakukan oleh pengabdi membuahkan hasil yang baik. Kegiatan yang dilakukan secara daring yang memanfaatkan platform pertemuan online berhasil mengundang peserta kegiatan sebanyak 70 orang yang berasal dari latar belakang pendidikan berbeda. Hal ini dapat kami ketahui meninjau dari hasil form pendaftaran kegiatan. Narasumber yang mengisi acara kegiatan web seminar ini berjumlah dua orang yang ahli di bidang ilmu sosial dan bidang ilmu psikologi, profil narasumber pertama merupakan seorang dosen yang memiliki latar belakang ilmu sosial khususnya pada fenomena kemasyarakatan yakni bapak Dr. Faraz, S.IP., MM. lalu narasumber kedua merupakan seorang mahasiswa yang sedang menempuh studi S2 jurusan Psikologi yakni Achmad Sholeh, S.Psi dan beliau membahas materi mengenai keterkaitan antara fenomena intoleransi dengan kondisi psikologis seseorang dalam bersosial media, dimana hal fenomena intoleransi yang terjadi kini semakin marak terjadi juga di dunia maya.

\section{HASIL DAN PEMBAHASAN}

Setelah dilakukan program web seminar 'Islamic Tolerance in World 4.0'. Seluruh data yang terkumpul selanjutnya dianalisis dan disajikan dalam bentuk tabel. Hasil data terlebih dahulu diuji dengan menggunkan uji hipotesis paired sample pre-test dan post-test menggunakan software SPSS versi 24.0 untuk windows.

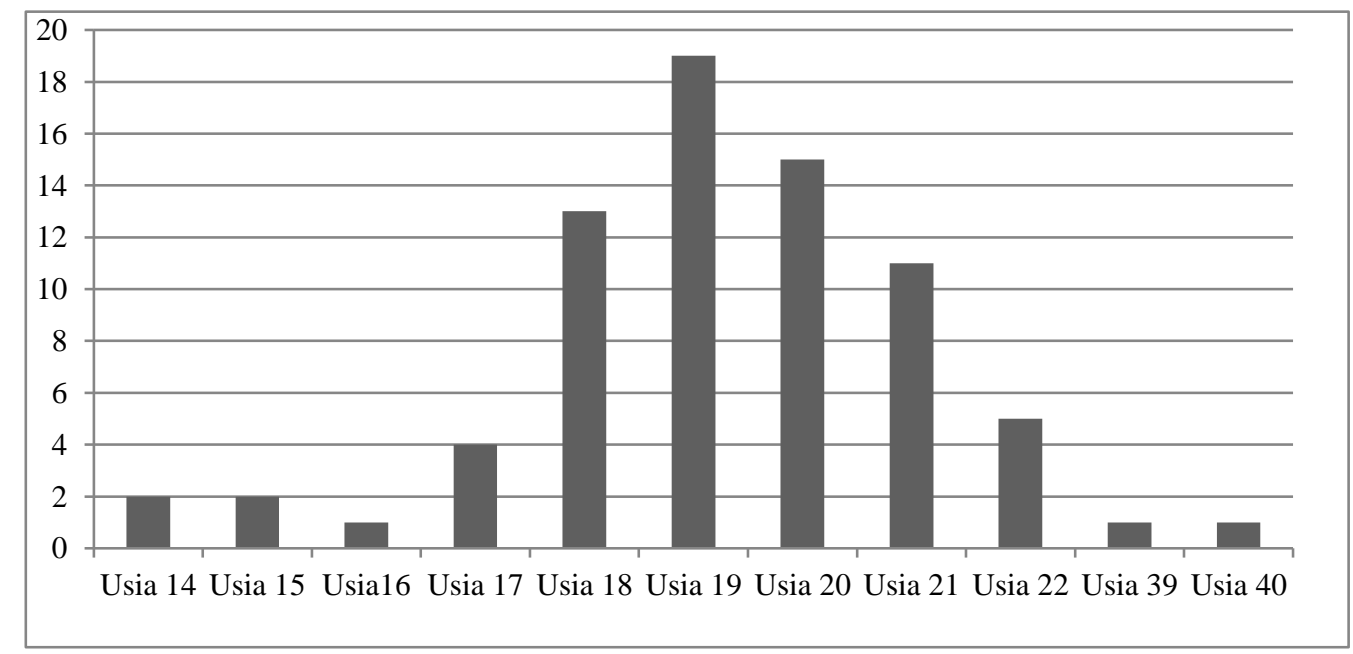

(Diagram 1. Sebaran Usia Peserta Kegiatan Web Seminar)

Pada diagram diatas menunjukan bahwa perserta web seminar berusia 14 tahun sampai dengan usia 40 tahun. Sedangkan rata-rata peserta yang mengikuti web seminar ini adalah mahasiswa yang berusia 19 tahun. 


\begin{tabular}{|c|c|c|}
\hline Variabel & Mean & Std. Deviation \\
\hline Pretest & 61,55 & 6,113 \\
\hline Postest & 62,72 & 6,465 \\
\hline
\end{tabular}

(Tabel 1. Hasil Rerata Skor Pre-Test dan Post-Test Kegiatan)

Berdasarkan tabel hasil dari paired sample pretest dan posttest, diketahui bahwa rerat pretest peserta kegiatan sebesar 61,55 dengan nilai standar deviasi sebesar 6,113. sedangkan pada hasil pengukuran akhir atau post-test diketahui bahwa rerata skor yang diperoleh peserta menunjukkan angka 62,72 dengan nilai standar deviasi sebesar 6,465.

\begin{tabular}{|l|l|}
\hline \multicolumn{1}{|c|}{ Variabel } & \multicolumn{1}{c|}{ PostTest-PreTest } \\
\hline $\mathrm{Z}$ & $-2.226^{\mathrm{b}}$ \\
\hline Asymp, Sig. (2-tailed) &, 026 \\
\hline
\end{tabular}

(Tabel 2. Hasil Analisis Uji Wilcoxon)

Berdasarkan uji analisis yang dilakukan dengan menggunakan Wilcoxon Test didapatkan hasil sig (2-tailed) $=0,026$ yang mana nilai $\mathrm{p}<0,05$ artinya adanya pengaruh signifikan antara sebelum dan sesudah dilakukannya program web seminar sehingga dapat disimpulkan bahwa kegiatan seminar berbasis online yang telah dilakukan dapat meningkatkan sikap toleransi masyarakat.

\section{PEMBAHASAN}

Program web seminar ini bertujuan untuk meningkatkan toleransi mahasiswa serta untuk mengetahui apakah adanya peningkatan dalam bertoleransi. Peserta webinar ini terdiri dari laki-laki dan perempuan yang berusia antara 14 sampai usia 40 tahun, dengan total peserta sebanyak 74 peserta. Berdasarkan hasil webinar ini, menunjukkan bahwa adanya pengaruh dalam peningkatan toleransi. Hal tersebut dapat dilihat dari hasil presets dan posttes yang dimana pretest menunjukan hasil 61,55, sedangkan setelah diberikan posttest menunjukan hasil 62,72. Dalam hal ini dapat dikatakan adanya pengaruh yang signifikan antara sebelum mengikuti web seminar dan sesudah mengikuti web seminar.

Menurut Casram (2016) hakekat toleransi adalah hidup berdampingan secara damai dan saling mengharga di antara keragaman. Dalam penelitian Nisvilyah (2013) menunjukkan bahwa secara normatif nilai-nilai dasar yang menjadi landasan terbentuknya toleransi antar umat beragama adalah nilai agama dan nilai budaya. Sedangkan secara empirik terdiri atas nilai-nilai kemanusiaan, nasionalisme, historis, keteladanan tokoh masyarakat, dan nilai kesabaran.

Sedangkan Menurut Khotimah (2013) salah satu upaya untuk menanamkan nilai-nilai toleransi pada individu yang berkelanjutan dengan mengembangkan rasa saling pengertian terhadap umat agama lain diperlukan proses pembelajaran agama, penting untuk dipahami adalah karakterstik toleransi yaitu belajar dalam perbedaan, membangun saling percaya adalah salah satu modal sosial terpenting dalam penguatan masyarakat, selain itu saaling pengertian, dan menjunjung tinggi sikap saling menghargai juga harus dimiliki individu. Sikap intoleransi dapat muncul dikarenakan tingkat pemahaman nilai kebangsaan yang dimiliki oleh individu yang sempit maupun penanaman nilai agama yang ekslusif di sekolah Muawanah (2018).

Menurut Muawanah (2018) toleransi penting dimiliki oleh masyarakat dikarenakan belajar menghargai setiap pendapat antar individu bisa menjadi modal penting untuk menghindari perpecahan didalam kehidupan masyarakat. Toleransi beragama adalah salah satu wujud yang nyata dari sikap menghargai dalam masyarakat. Dikarenakan unsur agama adalalah hal yang krusial dan sensitif dimata masyarakat. Sikap toleransi juga dapat membuat antarmanusia menjadi lebih erat. Setiap agama mengajarkan sikap toleransi antar umat yang beragama berbeda. Dengan adanya sikap toleransi antar masyarakat akan menumbuhkan sikap nasionalisme. Jika sikap toleransi kurang maka akan memicu terjadinya pemicu konflik dikehidupan sehari-hari. Selain itu kurangnya sikap toleransi juga dapat diakibatkan dari rasa egois yang terlalu tinggi. Berdasarkan hasil dari analisis data pre test 
dan post test pada web seminar 'Islamic Tolerance in World 4.0'. Didapatkan hasil bahwa peserta yang mengikuti web seminar 'Islamic Tolerance in World 4.0' dapat meningkatkan toleransi.

\section{SIMPULAN}

Toleransi yaitu sikap saling menghormati serta menghargai individu lain atas keyakinan yang telah diyakini. Sikap toleransi ini mencakup perbuatan untuk saling menghargai individu lain ketika beribadah maupun melakukan kegiatan yang berkaitan dengan ajarannya masing-masing. Dalam membangun toleransi di Indonesia dengan keanekargaman suku dan agama, perlu adanya kesadaran dari setiap individu agar tetap terciptanya kerukunan dan kedamaian antar umat. Melalui kegiatan web seminar yang telah dilakukan, yakni bertajuk "Islamic Tolerence in World 4.0" dapat disimpulkan bahwa web seminar ini dapat memberi pengaruh yang efektif untuk meningkatkan sikap toleransi partisipan di era modern ini. Hal ini dapat terlihat dari nilai rerata skor hasil pengukuran awal yaitu pre-test dan skor pengukuran akhir setelah pelaksaan web seminar yaitu post-test mengalami kenaikan skor. Tak hanya itu kegiatan web seminar kami memberi perubahan yang cukup signifikan pada masyarakat terkait sikap toleransi yang dimiliki oleh setiap individu. Sehingga tujuan dari kegiatan ini mampu memberikan edukasi kepada masyarakat serta mampu meningkatkan sikap toleransi antar umat beragama khususnya umat muslim kepada umat non-muslim, dengan demikian dapat meminimalisir terjadinya konflik antar umat beragama.

Kepada peneliti selanjutnya, sebaiknya mencari topik yang lebih baik lagi yang dapat memberikan edukasi kepada masyarakat. Topik yang menarik akan membuat partisipan tertarik untuk berpartisipasi dan mengambil manfaat dari materi yang disampaikan. Dengan penyampaian materi yang dikemas secara ringan dan sistematis, maka akan dapat memberikan pemahaman kepada partisipan yang mengikuti kegiatan web seminar tersebut. Selain itu, ketika akan mengadakan web seminar sebaiknya panitia memperhatikan dan mengantisipasi kendala yang akan terjadi, seperti koneksi internet yang harus stabil, serta dalam mengkoordinasikan partisipan dalam acara perlu dipersiapkan secara matang, dan sebagainya.

\section{UCAPAN TERIMAKASIH}

Penulis mengucapkan terima kasih yang sebesar-besarnya kepada Rektor Universitas Islam Indonesia, Prof. Fathul Wahid, S.T., M.Sc., Ph.D dan DPPM Universitas Islam Indonesia yang telah menugaskan penulis untuk membuat naskah jurnal publikasi ini masa periode November - Desember 2020:, Terimakasih kami sampaikan kepada dosen pengampu kami bapak Dr. Ahmad Rusdi, S.Psi., S.Sos.I., MA., Si. yang telah memberikan bimbingan kepada kami dan mendukung secara penuh untuk melakukan kegiatan seminar berbasis online di tengah situasi pandemi, tak lupa kami para penulis yang telah berkontribusi untuk menyusun naskah publikasi ini Annisa T R, Sabrina Adani Widiatmoko, Oksita Nurma Gupita, Fitri wulandari, Keny Pek, dan Fahmi Eko Nur Iman.

\section{DAFTAR PUSTAKA}

BBC. (2018). Serangan Bom Di Tiga Gereja Surabaya: Pelaku Bom Bunuh Diri "Perempuan Yang Membawa Dua Anak". Retrieved October 8, 2020, from https://www.bbc.com/indonesia/indonesia-44097913

Broer, N. A., De Muynck, B., Potgieter, F. J., Wolhuter, C. C., \& Van Der Walt, J. L. (2014). Measuring religious tolerance among final year education students: The birth of a questionnaire. IJRF, 7(2), 77-96.

Casram, C. (2016). Membangun sikap toleransi beragama dalam masyarakat plural. Wawasan: Jurnal Ilmiah Agama Dan Sosial Budaya, 1(2), 187-198. https://doi.org/10.15575/jw.v1i2.588

Institue, S. (2018). Laporan Tengah Tahun Kondisi Kebebasan Beragama Dan Berkeyakinan Dan Minoritas Keagamaan Di Indonesia 2018. Retrieved October 8, 2020, from https://setarainstitute.org/laporan-tengah-tahun-kondisi-kebebasan-beragama-dan-berkeyakinan-danminoritas-keagamaan-di-indonesia-2018/

Izza, S., Ningrum, B. S., \& Hariyati, R. T. S. (2019). Pemanfaatan webinar dalam bidang 
keperawatan. Jurnal Penelitian Perawat Profesional, 1(1), 13-20. https://doi.org/10.37287/jppp.v1i1.14

Khotimah. (2019). Toleransi beragama. Jurnal Ushuluddin, 20(2), 212-222. https://doi.org/10.31219/osf.io/ej5d8

Muawanah. (2018). Pentingnya pendidikan untuk tanamkan sikap toleran di masyarakat. Jurnal Vijjacariya, 5(1), 57-70. https://doi.org/10.31219/osf.io/vqgj4

Muharam, R. S. (2020). Membangun toleransi umat beragama di indonesia berdasarkan konsep deklarasi kairo. Jurnal HAM, 11(2), 269. https://doi.org/10.30641/ham.2020.11.269-283

Nisvilyah, L. (2013). Toleransi antarumat beragama dalam memperkokoh persatuan dan kesatuan bangsa (studi kasus umat islam dan kristen Dusun Segaran Kecamatan Dlanggu Kabupaten Mojokerto) Kabupaten Mojokerto). Kajian Moral Dan Kewarganegaraan, 2(1), 382-396.

Putra, E. P. (2020). Kronologi Vandalisme di Mushola Darussalam Tangerang. Retrieved October 8, 2020, from https://republika.co.id/berita/qhg1i1484/kronologi-vandalisme-di-musholadarussalam-tangerang

Yulianto, E., Cahyani, P. D., \& Silvianita, S. (2020). Perbandingan kehadiran sosial dalam pembelajaran daring menggunakan whatsapp groupdan webinar zoom berdasarkan sudut pandang pembelajar pada masa pandemic covid-19. JARTIKA: Jurnal Riset Teknologi Dan Inovasi Pendidikan, 3(2), 331-341. https://doi.org/10.36765/jartika.v3i2.277 